\title{
Leaf Anatomical-Histophytochemical Study and Evaluation of the Cytotoxicity of Ottonia frutescens Trel (Piperaceae)
}

\author{
Wendel Mattos Pompilho ${ }^{1(\mathbb{D})}$, Milton Masahiko Kanashiro ${ }^{2(\mathbb{D})}$, Tânia Toledo de Oliveira ${ }^{3}$, , Marcelo \\ Augusto Filardi ${ }^{3, *}{ }^{\mathbb{D}}$, Lara Maia Siqueira ${ }^{3}{ }^{\mathbb{D}}$, Marcelo Rocha da Costa ${ }^{3}(\mathbb{D})$, \\ Liovando Marciano da Costa 4 (D) \\ 1 Northwest Fluminense of Higher Education Institute, State University of North Fluminense, Santo Antônio de Pádua, RJ, \\ Brazil \\ 2 Bioscience \& Biotechnology Center, Recognizing Biology Laboratory, State University of North Fluminense, Campos \\ dos Goytacazes, RJ, Brazil \\ 3 Department of Biochemistry and Cell Biology, Federal University of Viçosa, 36571-000, Minas Gerais, Brazil \\ 4 Soil Science, UFV, MG, Brazil \\ * Correspondence: marcelo.filardi@ufv.br;
}

Scopus Author ID 7003705860

Received: 19.07.2020; Revised: 16.08.2020; Accepted: 17.08.2020; Published: 20.08.2020

\begin{abstract}
To investigate the leaf histochemistry and micromorphology of Ottonia frutescens Schltdl Trel (Piperaceae), the antioxidant potential, and in vitro cytotoxic bioactivity of the leaf extract of this species against human leukemia and colorectal cells. Leaf micromorphology and histoanatomy were detailed and recorded by optical and transmission and scanning electron microscopy. The histochemical results reveal classes of secondary phytometabolites such as alkaloids, anthraquinones, coumarins, polyphenols, and saponins. Cardiotonics, flavonoids, and triterpenes compounds were not detected. All concentrations of leaf extracts showed a significant dose-dependent and time-dependent apoptotic effect with more than $90 \%$ apoptosis of U937 cells and about $60 \%$ apoptosis of COLO-205 cells in $24 \mathrm{~h}$ of culture under $200 \mu \mathrm{g} / \mathrm{mL}$ of leaf extract. In addition, the phenolic compounds present in the fractions of the sample contribute to its strong antioxidant capacity. Ottonia frutescens exhibit anatomical and histochemical characteristics similar to other Piperaceae, and for the first time, provides a new source for secondary metabolite classes that exhibit high antioxidant potential and cytotoxic bioactivity, reduce cell viability and induce apoptosis in U937 leukemic cells and COLO-205 colorectal cells.
\end{abstract}

Keywords: Ottonia frutescens; Piperaceae; Leukemia; Colorectal cancer; Phytochemical.

(C) 2020 by the authors. This article is an open-access article distributed under the terms and conditions of the Creative Commons Attribution (CC BY) license (https://creativecommons.org/licenses/by/4.0/).

\section{Introduction}

Leukemia is among the ten most common cancers in the number of deaths worldwide [1], and most of the currently used chemotherapy drugs for cancers are known to develop resistance and restrictions by dose-limiting side effects [2]. Colorectal cancer is the fourth leading cause of cancer-related deaths worldwide [1,3]. The WHO Traditional Medicine Strategy 2014-2023 aims to develop proactive practices and implement action plans that will strengthen the role that traditional and complementary medicine plays in keeping populations healthy [4].

Plant-derived bioactive compounds, especially polyphenolic, have shown to reduce tumorigenesis, interfering in the initiation, promotion, and progression of cancer by modulating 
different enzymes and receptors in signal transduction pathways related to cellular proliferation, differentiation, apoptosis, inflammation, angiogenesis, metastasis and reversal of multidrug resistance [5-9].

The Piperaceae family has approximately 2000 species distributed mainly in tropical areas and exhibits potential as a drug source based on the use of some species in traditional medicine [10-13]. Many species exhibit classes of secondary metabolites with highly significant pharmacological potential. Iridoids, anthraquinones, triterpenes, alkaloids, flavonoids, phenolic derivates, and terpenoids stand out [11,13-15] with molecular mechanisms in the biochemical pathways that trigger the cell death investigated [16-19]. Research has pointed to the in vivo and in vitro anti-tumor potential of many species of the Piperaceae family [19-22], including leukemia [14,19,23] and colorectal cancer [16,20,23]. This is the first scientific investigation of the anti-tumor action of Ottonia frutescens (Piperaceae) and the first anatomical-histophytochemical and potential antioxidant study of this species. This plant provides a new source for classes of secondary metabolites, exhibits antioxidant potential and anti-tumor cytotoxic effect.

\section{Materials and Methods}

\subsection{Plant material.}

The botanical material was collected in a region in the Atlantic Forest in the ombrophyla vegetation in red-yellow latosol on the Santa Rita farm located in the Rio Paraíba do Sul watershed, in the West Forest Zone of the State of Minas Gerais (20 46' S and $42^{\circ} 02^{\prime}$ W). The annual temperature varies from $16^{\circ} \mathrm{C}$ to $28^{\circ} \mathrm{C}$, and the annual average rainfall is 2268 $\mathrm{mm}$. Leaves of adult specimens of Ottonia frutescens (Piperaceae) collected with the aid of pruning shears were duly identified, and a voucher specimen was deposited in the Guido Pabst - GFJP herbarium, Itaperuna - RJ, Brazil, registered under GFJP-204.

\subsection{Optical microscopy.}

Leaf fragments of the selected species were placed in an aqueous solution containing $2.5 \%$ glutaraldehyde and $4.0 \%$ formaldehyde diluted in $0.05 \mathrm{M}$ of sodium cacodylate buffer, $\mathrm{pH} 7.2$, at room temperature for $2 \mathrm{~h}$. After washing the fragments for $45 \mathrm{~min}$ in the same buffer, they were then placed in an aqueous solution containing $1 \%$ osmium tetroxide diluted in $0.05 \mathrm{M}$ of sodium cacodylate buffer, $\mathrm{pH} \sim 7.2$, at room temperature for 1 hour with the absence of light. After three 45 min washes in the same buffer, the fragments were submitted to an ascending ketone series $[50 \%, 70 \%, 90 \%, 100 \%(3 \mathrm{x})]$ for 1 hour at each step for dehydration. Next, the fragments were infiltrated with epoxy resin (Epon PolibedTM), using an increasing resin series in propanone. The polymerization of the resin was performed at 60 ${ }^{\circ} \mathrm{C}$. Semi-thin sections $(1 \mu \mathrm{m}$ thick) were obtained with ultramicrotome glass cutters (Reichert Ultracut- $S^{\circledR}$ ). The staining was performed with a $1 \%$ toluidine blue aqueous solution, plus $0.1 \%$ of Borax. Permanent blades were assembled with Entellan ${ }^{\circledR}$ for optical digital documentation (Axioplan Zeiss Canon ${ }^{\circledR}$ Power Shot 14 mpixel; Oberkohen, Germany).

\subsection{Transmission electron microscopy.}

Ultra-thin sections ( $70 \mathrm{~nm}$ thick) were obtained using a diamond knife (Diatome ${ }^{\circledR}$ ) in ultramicrotome (Leica Reichert Ultracut-S ${ }^{\circledR}$, Germany), collected in 300 mesh copper grids. 
The staining was performed in a saturated aqueous solution of uranyl acetate (40 $\mathrm{min}$ ) followed by washing in distilled water $(5 \mathrm{~min})$ in a $1 \%$ lead citrate [24]. The images were obtained through transmission electron microscopy (Zeiss ${ }^{\circledR}$ EM900) under an accelerating voltage of 80 $\mathrm{kV}$, with the aid of the iTEM (Olympus ${ }^{\circledR}$ ) program.

\subsection{Scanning electron microscopy.}

After dehydration, the samples were dried by the $\mathrm{CO}_{2}$ critical point method (Bal-Tec ${ }^{\circledR}$ SCD-050 Sputter Coater, Liechtenstein). Dry leaf fragments were attached to appropriate stands with double-face carbon adhesive tape (3M) and carbon glue, covered by sputtering a layer of approximately $20 \mathrm{~nm}$ of gold (Bal-Tec ${ }^{\circledR}$ SCD-050 Sputter Coater, Liechtenstein). Samples were observed under a scanning electron microscope (DSM 962 and EVO 40-Zeiss ${ }^{\circledR}$ ) at an accelerating voltage of $15 \mathrm{kV}$ or $25 \mathrm{kV}$.

\subsection{Histochemical analysis of the plant sample.}

Histochemical tests of freshly collected leaf material were performed using freehand vegetable cuttings. Acid and base compounds were evaluated from exposure of the plant sections for $10 \mathrm{sec}$ to a toluidine blue $0.05 \%$ aqueous solution at $\mathrm{pH} 6.8$ [25]. Alkaloids were evaluated by Dragendorff's reagent for 5 to $10 \mathrm{~min}$ and washed quickly in sodium nitrite, $5 \%$, and subsequently in water [26]. Total proteins were evaluated by Coomassie brilliant blue G, $0.25 \%$ (acetic acid, $5 \%$ for $30 \mathrm{~min}$ ), and washed in $5 \%$ aqueous acetic acid three times for 5 min at each stage; semi-permanent slides were assembled with glycerin, 50\%. Phenolic compounds were detected by an aqueous solution of ferric chloride (10\%, $5 \mathrm{~min}$ ); peptic substances were detected using an aqueous solution of ruthenium red $(0.05 \%, 10 \mathrm{sec})$. Acid intracellular compartments were evaluated by an aqueous solution of acridine orange $(0.01 \%$, 5 min) [27]. Lipids were evaluated by the Sudan IV test, 0.03\% [28].

\subsection{Plant extract.}

O. frutescens leaves were submitted to forced ventilation drying, at a constant temperature of $40{ }^{\circ} \mathrm{C}$, until stabilization of the weight, to obtain dry plant matter; $350 \mathrm{~g}$ of leaves were ground with a mortar and pestle in the presence of liquid nitrogen. The material with reduced particle size was deposited in an amber flask and extracted by maceration in $10 \%$ (w/v) methanol for seven days at room temperature. The period for exhaustive extraction was 21 days. Every seven days, the fluid extractor was filtered, and a new fluid extractor was added. The obtained extract was concentrated in a rotary evaporator, and the drying process of the extract was finalized under direct ventilation $\left(40\right.$ to $\left.50{ }^{\circ} \mathrm{C}\right)$. Finally, the dried extract was verified and stored in an opaque plastic container in the presence of a desiccant agent.

\subsection{Phytochemical prospecting of extracts.}

The phytochemical analysis of the methanolic extract of the $O$. frutescens leaves was performed in thin layer chromatography [29]. The following groups of secondary metabolites were evaluated: Alkaloid, Anthraquinones, Cardiotonics, Coumarins, Flavonoids, Polyphenols (Tannins), Saponin, and Triterpene. In the chromatographic process, mobile phases, developers, and specific reference standards were used for each of the groups of secondary metabolites (Table 1). 


\begin{tabular}{|c|c|c|c|c|}
\hline $\begin{array}{l}\text { Metabolite } \\
\text { group }\end{array}$ & Mobile phase & Developer & Standard & Reference \\
\hline Alkaloids & $\begin{array}{l}\text { Ethyl methanol-water acetate } \\
\qquad(100: 14: 10)\end{array}$ & Dragendorff's Reagent & Quinine & [26] \\
\hline Anthraquinones & $\begin{array}{l}\text { Ethyl methanol-water acetate } \\
\text { (100:17: 13) }\end{array}$ & $\begin{array}{l}5 \% \mathrm{KOH} \text { solution in } \\
\text { ethanol }\end{array}$ & $\begin{array}{l}\text { 1,8-dihydroxy- } \\
\text { anthraquinone }\end{array}$ & [29] \\
\hline Cardiotonics & $\begin{array}{l}\text { Ethyl methanol-water acetate } \\
\qquad(81: 11: 8)\end{array}$ & Kedde's Reagent & Digitoxin & {$[27]$} \\
\hline Coumarins & $\begin{array}{l}\text { Acetic acid-toluene-diethyl ether- } \\
\text { water }(50: 25: 25: 5)\end{array}$ & $\begin{array}{l}5 \% \mathrm{KOH} \text { solution in } \\
\text { ethanol }\end{array}$ & Benzopyrone & [26] \\
\hline Flavonoids & $\begin{array}{l}\text { Ethylacetate-acetic acid-acetic } \\
\text { acid-water }(55: 5: 5: 1)\end{array}$ & $\begin{array}{l}5 \% \mathrm{AlCl}_{3} \text { solution in } \\
\text { ethanol }\end{array}$ & Routine & [29] \\
\hline $\begin{array}{l}\text { Polyphenols } \\
\text { (Tannins) }\end{array}$ & $\begin{array}{l}\text { Toluene-butanol-acetic acid } \\
\text { (80:40:16) }\end{array}$ & Barton's Reagent & Pirogalic acid & [28] \\
\hline Saponin & $\begin{array}{l}\text { Chloroform-glacial acetic acid- } \\
\text { methanol-water }(15: 8: 3: 2)\end{array}$ & Sulfuric anisaldehyde & 18 - $\beta$-glycyretin & {$[28]$} \\
\hline
\end{tabular}

\subsection{Evaluation of the antioxidant activity of the extract.}

The antioxidant capacity of the extract was determined using the stable radical method 2,2-diphenyl-1-picrylhydrazyl (DPPH), and is based on the free radical reduction DPPH [30]. The solution prepared daily was stored away from the light and kept at $4^{\circ} \mathrm{C}$ until use. The final concentrations of the sample were $3,6,12,18,24 \mu \mathrm{g} / \mathrm{mL}$. The samples were diluted in methanol at five different concentrations: $30,60,120,180,240 \mu \mathrm{g} / \mathrm{mL} .300 \mu \mathrm{L}$ of each of the five concentrations was added in $2.7 \mathrm{~mL}$ of a DPPH methanolic solution $(60 \mu \mathrm{M})$. The control was prepared from $2.7 \mathrm{~mL}$ of the solution of DPPH plus $300 \mu \mathrm{L}$ of methanol. A blank was performed with the extract, fractions, and controls to reduce the contribution of the color to the absorbance. The absorbance of the samples was measured at 0, 15, 30, and $45 \min (515 \mathrm{~nm})$ times in quartz cuvettes. The antioxidant activity of the sample, in the percentage of DPPH (Absorbance, $\mathrm{Ab}$ intake), was obtained by the formula [Ab control - (Ab sample - Ab white) / Ab control] x 100 .

\subsection{Evaluation of the extract effect on the cell line' viability.}

U937 leukemia human cells of lymphoid origin (ATCC ${ }^{\circledR}$ CRL1593.2 ${ }^{\mathrm{TM}}$ ) and COLO205 colorectal adenocarcinoma human cells $\left(\right.$ ATCC $^{\circledR}$ CCL222 $^{\mathrm{TM}}$ ) were cultured in D-MEM F12 medium (Gibco ${ }^{\circledR}$, BRL) supplemented with $20 \mu \mathrm{g} / \mathrm{mL}$ of gentamicin (Gibco ${ }^{\circledR}, \mathrm{BRL}$ ) and $10 \%$ of fetal bovine serum $\left(\mathrm{Gibco}^{\circledR}, \mathrm{BRL}\right)$. Cultures were replicated every 2 days and kept in an incubator (Forma Scientific ${ }^{\circledR}$ Inc., model 3159) at $37^{\circ} \mathrm{C}$, with $5 \%$ of $\mathrm{CO} 2$ and controlled humidity.

Cell viability was assessed from the assays with 3-(4.5-dimethyl-2-thiazole) 2.5diphenyl-2-H-bromide of tetrazolium, MTT [31] and from release levels of the lactic dehydrogenase enzyme [32]. Cells were plated in a volume of $100 \mu \mathrm{L} /$ well $\left(1 \times 10^{6}\right.$ cells $\left./ \mathrm{mL}\right)$ in 96-well plates and exposed to the extracts of $O$. frutescens at the final concentrations of 50, 100,200 and $400 \mu \mathrm{g} / \mathrm{mL}$ and kept in an incubator at $37{ }^{\circ} \mathrm{C}$, with $5 \% \mathrm{CO} 2$ and controlled humidity. After $24 \mathrm{~h}$ under cell culture with the extracts, cell viability assays were performed. For this, $10 \mu \mathrm{L}$ of MTT $\left(\right.$ Sigma $^{\circledR}$ ) in a $100 \mu \mathrm{L}$ culture was added for further spectrophotometric reading (Thermo Scientific Multiskan-Ex ${ }^{\circledR}$ ) at $570 \mathrm{~nm}$. 
2.10. Evaluation of lactate dehydrogenase ( $L D H)$.

To evaluate $\mathrm{LDH}$ release (Doles ${ }^{\circledR} \mathrm{Kit}$, Brazil), $50 \mu \mathrm{M}$ of the supernatant was transferred to another 96-well plate containing $100 \mu \mathrm{M}$ of solution $\mathrm{A}(250 \mu \mathrm{M}$ of ferric alum solution + $400 \mu \mathrm{M}$ of the substrate) and kept in an incubator for $3 \mathrm{~min}$. Afterward, $100 \mu \mathrm{M}$ of solution B $\left(225 \mu \mathrm{M}\right.$ FMS / NAD ${ }^{+} 4275 \mu \mathrm{M}$ solution of distilled water) were added and kept in an incubator for $7 \mathrm{~min}$ for subsequent spectrophotometric readings at $492 \mathrm{~nm}$ (Thermo Scientific Multiskan$\mathrm{Ex}^{\circledR}$ ). As negative controls, cells were incubated with DMEM F12 medium (Gibco $\left.{ }^{\circledR}, \mathrm{BRL}\right)$ supplemented with $20 \mu \mathrm{g} / \mathrm{mL}$ of gentamicin (Gibco ${ }^{\circledR}, \mathrm{BRL}$ ) and $10 \%$ fetal bovine serum $\left(\right.$ Gibco $\left.^{\circledR}, \mathrm{BRL}\right)$. For the assays with the extracts, the cells were incubated with $1 \%$ DMSO $\left(\right.$ Sigma $\left.{ }^{\circledR}\right)$. The experiments were carried out in triplicates.

\subsection{Evaluation of apoptosis through fluorescence microscopy.}

The leukemic cells U937 and colorectal COLO-205 cells exposed at 12, 24 and $36 \mathrm{~h}$ with different concentrations of the extract were stained with $10 \mu \mathrm{g} / \mathrm{mL}$ of acridine orange solution $\left(\right.$ Sigma $\left.^{\circledR}\right)$ and $10 \mu \mathrm{g} / \mathrm{mL}$ of ethidium bromide $\left(\right.$ Sigma $\left.^{\circledR}\right)$. In random fluorescence microscopy (Axioplan Zeiss ${ }^{\circledR}$ ) fields, $~ 300$ cells were evaluated for apoptosis and necrosis. Duplicates were made for each condition, and the experiments were repeated at least twice.

\subsection{Statistical analysis.}

The results were expressed as mean \pm standard deviation, analyzed independently and evaluated by one-way ANOVA followed by the Tukey test (GraphPad 5.0 Software, USA). All experiment samples were made into triplicates and repeated at least three times. Statistically significant differences were defined for $\mathrm{p}<0.05$, $\mathrm{p}<0.01$, and $\mathrm{p}<0.001$.

\section{Results and Discussion}

\subsection{Foliar micromorphology and anatomy.}

O. frutescens exhibits a regular abaxial surface, epidermal cells with irregularly contoured anticline walls, and a straight external periclinal wall with layered epicuticular wax; the notable presence of secretory trichomes and multicellular tectors (Figure $1 \mathrm{AB}$ ), a botanical characteristic common to the Piperaceae family [33-35]. The leaves are hypostomatic with rare paracytic stomata.
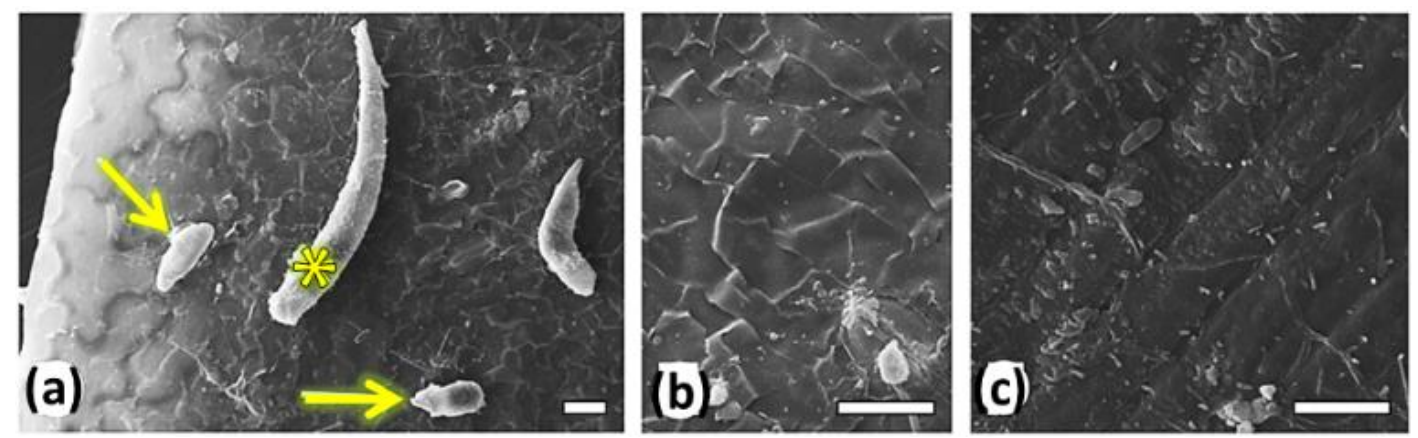

Figure 1. Scanning electron microscopy of $O$. frutescens leaf. (a) Frontal view of the abaxial epidermis showing the presence of multicellular tector type trichomes (*) and secretory trichomes (arrows); Bar: $20 \mu$ m. (b) Detail of the abaxial surface covered by layered wax; Bar: $200 \mu \mathrm{m}$. (c) Adaxial surface covered by smooth to slightly granular wax; Bar: $10 \mu \mathrm{m}$. 
The adaxial surface is glabrous with periclinal cell walls and anticlinal wax covered with mild granulation in some areas (Figure 1C). Leaves of O. frutescens display micromorphological characteristics common to the Piperaceae family, similar to those described for O. martiana [33,36], Piper mosenii [34], Peperomia pellucida and Piper longum [35].

The leaf blade of $O$. frutescens presents both an epidermis constituted by a single layer of isodiametric cells with varied sizes and a straight periclinal wall, the abaxial cell face being smaller than the adaxial ones (Figure 2), botanical characteristics also observed in other species of the Piperaceae family [35], while other species exhibit multiple epidermal tissues, an adaptive botanical characteristic of heliophylous [33]. In this study, no adaxial or abaxial monoserial subepidermal was observed, photoprotective tissue described in other Piperaceae species [33,37,38], including O. martiana [36]. The mesophile is dorsiventral consisting of palisade parenchyma formed by a cell layer rich in chloroplasts and lacunar parenchyma consisting of 4 to 6 isodiametric cell layers with small intercellular spaces. The leaf anatomy of $O$. frutescens display characteristics common to the Piperaceae family [33-36].

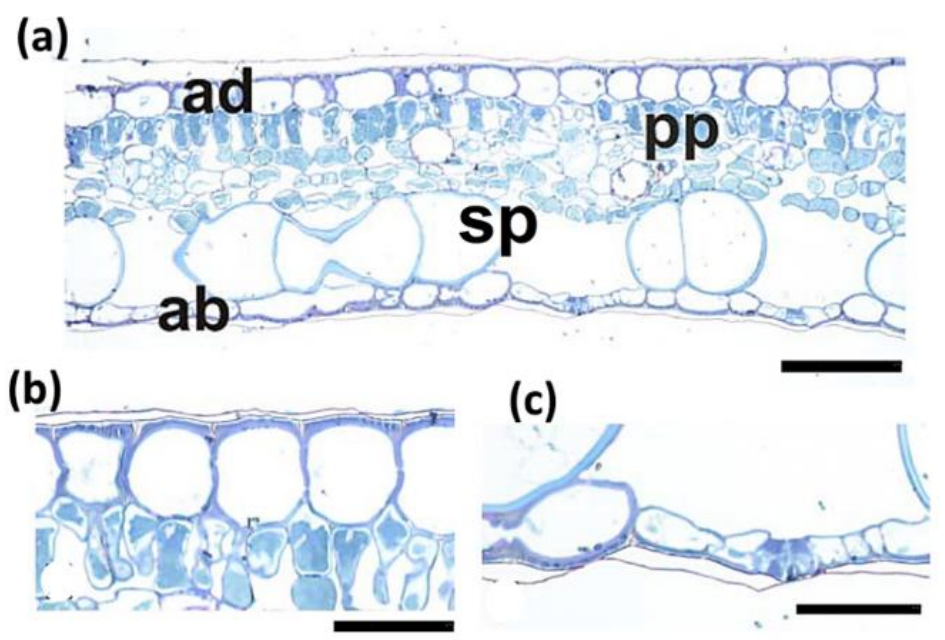

Figure 2. Leaf-blade of $O$. frutescens in the transverse section under optical microscopy (a), with detail of uniserial adaxial epidermis (b) and abaxial epidermis (c). Abbreviations: ad, adaxial surface; ab, abaxial surface; pp, palisade parenchyma; sp, spongy parenchyma. Bars: A: $50 \mu \mathrm{m}$; BC: $25 \mu \mathrm{m}$.

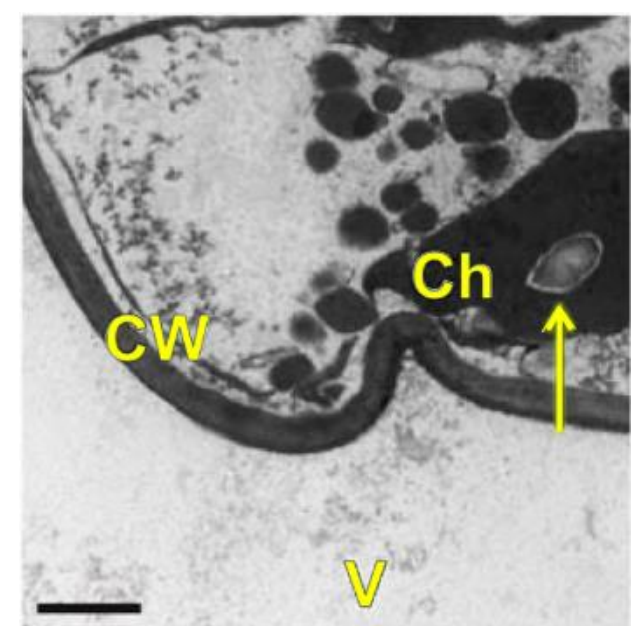

Figure 3. Transmission electron microscopy of $O$. frutescens leaf. A cell of the spongy parenchyma showing a large vacuole $(\mathrm{V})$, thin cell wall $(\mathrm{CW})$, and chloroplast with starch accumulation (arrow). Bar: $1 \mu \mathrm{m}$. 
Under transmission electron microscopy, it was possible to observe that the external periclinal wall of $O$. frutescens presents a basal polysaccharide layer followed by cuticular extracts divided into arborescent (closest to the polysaccharide layer) and reticulated (more above this extract). Protoplast observation of mesophilic cells revealed common plant cytological features such as the presence of large central vacuoles, cytoplasm occupying a relatively small and peripheral volume, and abundant chloroplasts with starch accumulation (Figure 3).

\subsection{Foliar histochemistry.}

The Coomassie blue test for proteins and Dragendorff reagent for alkaloids revealed intense markings in the palisade and spongy parenchyma of $O$. frutescens. The ferric chloride test also exhibited markings mainly on the palisade parenchyma (Figure 4A). The staining with acridine orange revealed a predominance of the markings in the adaxial and abaxial epidermis, and in the chlorophyllic parenchyma (Figure 4B).

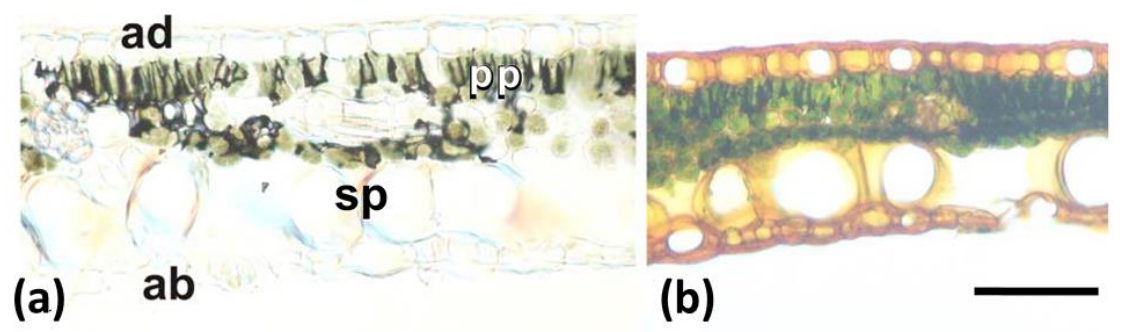

Figure 4. Optical microscopy of the leaf sections of $O$. frutescens submitted to histochemical tests of ferric chloride (a) and acridine orange (b). Abbreviations: ad - adaxial surface; ab - abaxial surface; pp - palisade parenchyma; sp - spongy parenchyma. Bar: $50 \mu \mathrm{m}$.

Phytocomposites such as proteins, phenolic compounds, and alkaloids are more concentrated in the leaf parenchymatic region. The leaf epidermis exhibits reactive staining much more acid compartments and pectins than other sites on the leaf, but without reactive epidermal detection of alkaloids and phenolic compounds, lipids and proteins are poorly detected in epidermal cells (Table 2).

Table 2. Histochemistry of the $O$. frutescens leaf blade.

\begin{tabular}{c|c|c|c|c|c} 
& & & \multicolumn{2}{c}{ Leaf Mesophyll } & \\
\hline Reagent & Target Compound & $\begin{array}{c}\text { Adaxial } \\
\text { Epidermis }\end{array}$ & $\begin{array}{c}\text { Palisade } \\
\text { Parenchyma }\end{array}$ & $\begin{array}{c}\text { Spongy } \\
\text { Parenchyma }\end{array}$ & $\begin{array}{c}\text { Abaxial } \\
\text { Epidermis }\end{array}$ \\
\hline Coomassie Blue & Proteins & - & ++ & ++ & + \\
\hline Ferric Chloride & Phenolic Compounds & - & +++ & ++ & - \\
\hline Dragendorff & Alkaloids & - & +++ & +++ & - \\
\hline Acridine orange & Acid Compartments & +++ & - & + & +++ \\
\hline Ruthenium Red & Pectins & ++ & - & - & +++ \\
\hline Sudan IV & Lipids & + & + & + & +
\end{tabular}

Legend: +++ Very strong marking; ++ Moderately strong marking; + Poor marking; - Unmarked

\subsection{Phytochemical prospecting.}

Phytochemical prospection of foliar extracts of $O$. frutescens reveals the presence of alkaloids, anthraquinones, coumarins, polyphenols, and saponins, attributing recognized antitumor effects [39-41] including leukemic cells [42,43] and colorectal cancer [43-45]. 
Cardiotonics, flavonoids, and triterpenes compound not were detected. However, they have already been identified in considerable concentrations in other species of the Piperaceae family $[13,15,19]$. With similar results, tannins and coumarins have also been found in the phytochemical screening of extracts from other Piperaceae species, but with alkaloids, flavonoids and saponins also showing interspecific variations [10,12]. In addition to the interspecific characteristic, phytochemical diversity is related to several plant ecophysiological functions, including protection against biotic and abiotic environmental stresses [46-49], and it can change according to the geographical origin of the species and ecological characteristics, accounting for variations in bioactivity [15].

\subsection{Determination of the antioxidant activity of the extract.}

The antioxidant activity of the leaf extract of $O$. frutescens was evaluated (Table 3). The results were better than the antioxidant activity exhibited by other species of the family Piperaceae $[13,15,22,50]$.

Table 3. Percentage of the antioxidant activity of foliar extract of $O$. frutescens by the DPPH method, under final concentrations of 3, 6, 12, 18, $24 \mu \mathrm{g} / \mathrm{mL}$, for $30 \mathrm{~min}$. Mean \pm standard deviation obtained by triplicate.

\begin{tabular}{c|c|c|c|c}
\multicolumn{5}{c}{ Extract Concentration $(\boldsymbol{\mu g} / \mathbf{m L})$} \\
\hline 3 & 6 & 12 & 18 & 24 \\
\hline $2.7 \pm 0.7$ & $9.6 \pm 0.6$ & $12.5 \pm 0.6$ & $31.2 \pm 0.8$ & $38.3 \pm 0.6$
\end{tabular}

The phenolic compounds present in the fractions of the sample contribute to its antioxidant capacity, as observed for other Piperaceae [13,14,20,21]. In Piper sarmentosum, the strong antioxidant effect is highly correlated mainly to phytochemicals such as flavonoids and phenolic compounds whose concentrations can vary according to the geographical origin of the plant, interfering in the antioxidant potential of experimental leaf extracts [15].

\subsection{Effect of extracts on cell viability.}

The cytotoxic effect of the $O$. frutescens extract on human leukemic cell line U937, and human COLO-205 colorectal cells were evaluated. All concentrations tested showed a significant inhibitory effect in a dose-dependent relationship on cell viability, with greater than $90 \%$ inhibition of U937 cells and about $75 \%$ inhibition of COLO-205 cells in a concentration of $400 \mu \mathrm{g} / \mathrm{mL}$ after $24 \mathrm{~h}$ of incubation (Figure 5). The determination of the lethal dose 50 (LD50) was $230.9 \pm 1.73 \mu \mathrm{g} / \mathrm{mL}$ under $12 \mathrm{~h}$ of culture, $112.9 \pm 1.47 \mu \mathrm{g} / \mathrm{mL}$ in $24 \mathrm{~h}$ and 86.34 $\pm 2.32 \mu \mathrm{g} / \mathrm{mL}$ after $36 \mathrm{~h}$ of exposure of the U937 cells to the extract, and $<400 \mu \mathrm{g} / \mathrm{mL}$ under $12 \mathrm{~h}$ of culture, $280.0 \pm 1.19 \mu \mathrm{g} / \mathrm{mL}$ in $24 \mathrm{~h}$ and $257.5 \pm 1.31 \mu \mathrm{g} / \mathrm{mL}$ after $36 \mathrm{~h}$ of exposure of the COLO-205 cells to the leaf extract.
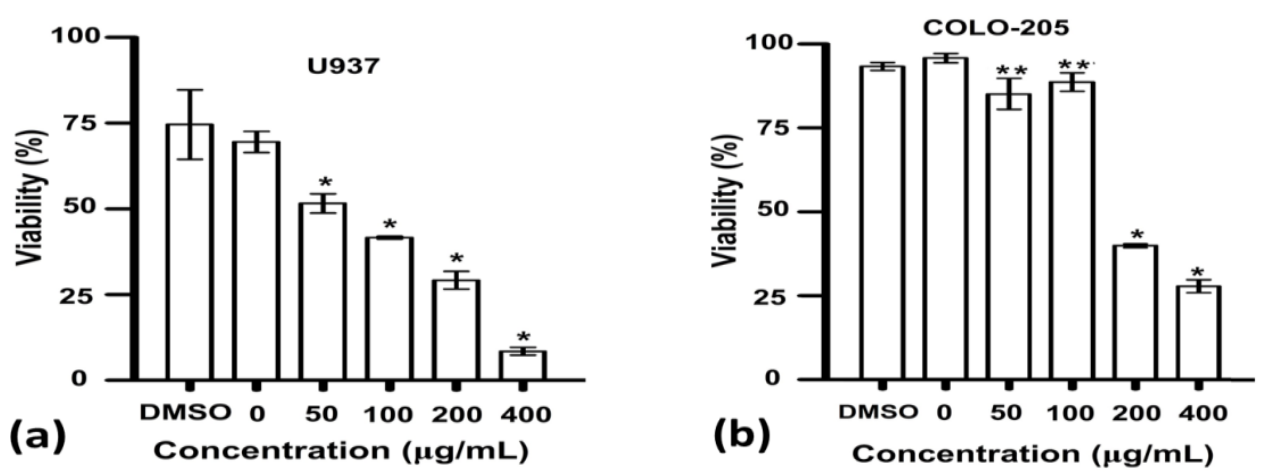
Figure 5. Cytotoxic effect of $O$. frutescens extracts on (a) human leukemic cell line U937 and (b) human colorectal cell line COLO-205 after $24 \mathrm{~h}$ incubation. ; (0): negative control; DMSO: positive control. * $\mathrm{P}<0.05$, $\mathrm{n}=3$. ANOVA, One-way Tukey.

Although other Piperaceae species exhibit confirmed in vivo and in vitro anticarcinogenic action [19,21,51], selectively with minimal cytotoxic effect on normal cells [10], this is the first investigative study on the anti-tumor bioactivity of leaf extract in the genus Ottonia, which somewhat limits the safe inference of the results obtained. On the other hand, it will contribute as a source of primary data for future scientific studies involving this genus.

Further studies at our research center will be conducted in order to understand the chemical composition of fractionated bioactive substances present in the plant extract and their effects on oncogenesis.

\subsection{Quantification of lactate dehydrogenase.}

As indicative of cell membrane damage and a key feature of cells undergoing apoptosis, necrosis, and other forms of cellular damage, the activity of the cytosolic enzyme Lactate Dehydrogenase (LDH) was evaluated. Statistically significant results were shown by the U937 leukemic cells for all tested concentrations of the $O$. frutescens foliar extract in a dosedependent effect, $200 \mu \mathrm{g} / \mathrm{mL}$ after $24 \mathrm{~h}$ of culture being the best result found for COLO-205 colorectal cells (Figure 6).
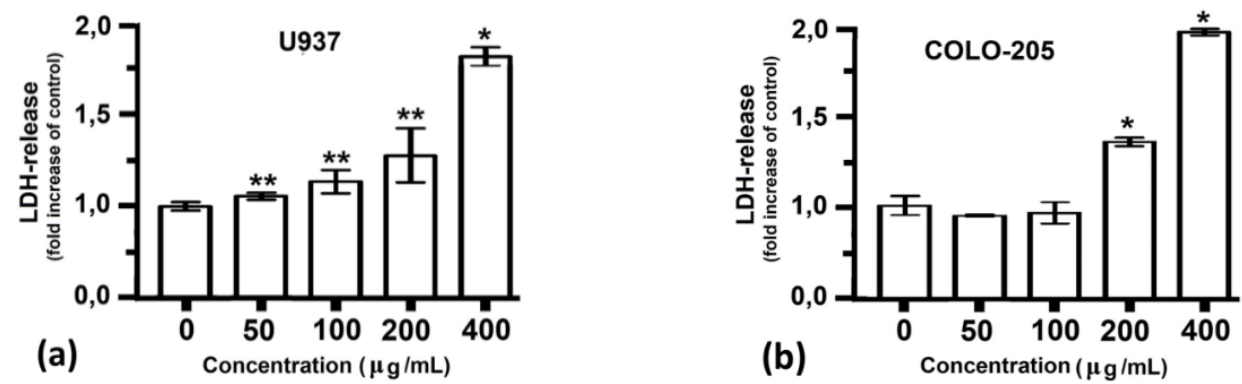

Figure 6. Evaluation of LDH release by (a) U937 leukemic cells and (b) COLO-205 colorectal cells after $24 \mathrm{~h}$ of incubation exposed to $O$. frutescens leaf extract. The results were presented as a fold increase of the control cells $(0) . * \mathrm{P}<0.05 ; * * \mathrm{P}>0.05, \mathrm{n}=3$. ANOVA One-way Tukey.

\subsection{Evaluation of apoptosis induction and cellular necrosis.}

To investigate the anti-tumor activity of $O$. frutescens leaf extract on U937 leukemic and COLO-205 colorectal cells, cell death was evaluated by fluorescence microscopy. All concentrations tested showed a significant dose-dependent and time-dependent apoptotic effect with more than $90 \%$ apoptosis of U937 cells and about 60\% apoptosis of COLO-205 cells in $24 \mathrm{~h}$ of culture under $200 \mu \mathrm{g} / \mathrm{mL}$ of leaf extract (Figure 7).
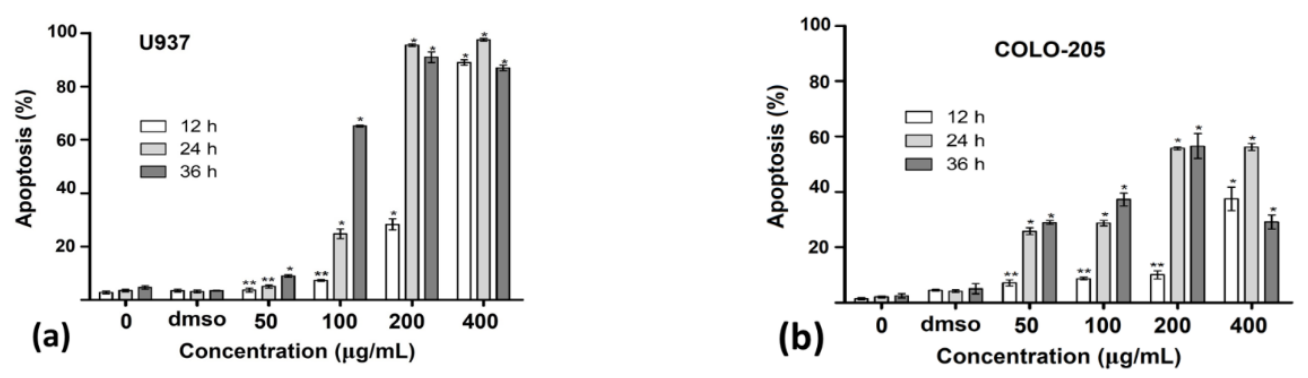
Figure 7. Percentage of apoptosis of U937 leukemic and COLO-205 colorectal human cells exposed to different concentrations of leaf extract of $O$. frutescens at 12, 24, and 36 h of culture; (0): negative control; DMSO: positive control. $* \mathrm{P}<0.05, * * \mathrm{P}>0.05, \mathrm{n}=2$. ANOVA, One-way Tukey.

There was a rate of less than $3 \%$ of U937 cell necrosis only at the concentration of 400 $\mu \mathrm{g} / \mathrm{mL}$ under $36 \mathrm{~h}$ of culture. There was $20 \%$ necrosis of COLO-205 cells already starting at $50 \mu \mathrm{g} / \mathrm{mL}$ under $36 \mathrm{~h}$ (data not shown). Other Piperaceae species traditionally used in different parts of the world and phytochemically investigated exhibit apoptotic effect in different tumor lines cells [21], including leukemia and colorectal [19,51].

Phytochemical studies of different Piperaceae species have drawn scientific interest $[12,14]$, and this is the first histophytochemical and anatomical study of $O$. frutescens, in particular focusing on tumor cells. Its cytotoxic effects on U937 leukemic and colorectal COLO-205 cells indicate a potential alternative in the treatment of these types of cancer. This plant provides a new source for classes of secondary metabolites: alkaloid, anthraquinones, coumarins, polyphenols, saponins, flavonoids and terpenes, which might be capable of inducing cancer cell apoptotic death [42,51,52]. Perspectives of scientific studies can be directed to studies on the interference of different environments in which $O$. frutescens is adapted, the histochemical and anatomical foliar variations and the relation with the phytochemical bioactivity of this Piperaceae and the different plant parts to U937 leukemic cells and COLO-205 colorectal cells and other lineages of human tumor cells.

Tests with crude extracts of plant organs provide good indications of the plant's bioactivity and the prospect of isolation of promising biocompounds for the development of new future anti-tumor drugs. However, there is a limitation of predicting whether the isolation of a certain $O$. frutescens biocompounds will present interesting experimental results if there is a synergy between the components of the leaf extract. Another limitation is to safely predict which chemical class most affected the viability of human leukemia and colorectal tumor cells. The experimental use of two cell types of cancers so different also brought some limitation in defining the comparative tests with a physiologically compatible cell control, since one cancer exhibits blood characteristics and other cancer with solid tumor characteristics. In addition, tests with extracts using different tumor cells also limit a safe interpretation of the results in relation to the possible mechanism of action, since they are different tumorigenic biochemical pathways for each type of cancer.

\section{Conclusions}

This, the first report, reveals that Ottonia frutescens exhibit anatomical and histochemical characteristics similar to other Piperaceae. This plant provides a new source for classes of secondary metabolites: alkaloid, anthraquinones, coumarins, polyphenols, saponins, flavonoids and terpenes. The leaf extracts exhibit high antioxidant potential and cytotoxic bioactivity, reduce cell viability, and induce apoptosis in U937 leukemic cells and COLO-205 colorectal cells. This plant should be further examined in different test systems to understand its potential cytotoxic properties and the biochemical pathways that interfere with tumor cell lethality.

\section{Funding}

This research received no external funding. 


\section{Acknowledgments}

The authors would like to thank the Toxifar Network of the Support Foundation of Minas Gerais Research (Fapemig) and Coordination of Improvement of Higher Level Personnel (Capes), for the financial support, the Federal University of Viçosa and the North Fluminense State University.

\section{Conflicts of Interest}

The authors declare no conflict of interest.

\section{References}

1. NCI. National Cancer Institute. Cancer Stat Facts: Leukemia. Bethesda, MD. 2020. [accessed 19 Feb 2020]. https://seer.cancer.gov/statfacts/html/leuks.html.

2. Yestemirova, G.A.; Yessimsiitova, Z.B.; Danilenko, M.P. Current progress in the study of acute myeloid leukemia. Int. J. Biol. Chem. 2020, 12, 86-92, https://doi.org/10.26577/ijbch-2019-i2-11.

3. Siegel, R.L.; Miller, K.D.; Jemal, A. Cancer statistics, 2020. CA: Can J Clin. 2020, 70, 7-30, https://doi.org/10.3322/caac.21590.

4. WHO, World Health Organization. Tradicional Medicine Strategy: 2014-2023. Geneva, 2013. Available at: https://www.who.int/medicines/publications/traditional/trm_strategy14_23/en/ (accessed 24 March 2020).

5. Jurisevic, M.; Bolevich, S. Complementary and alternative medicine applications in cancer medicine. Tradit. Med. Res. 2020, 5, 7-21, https://doi.org/10.12032/TMR20190728127.

6. Lage, N.N.; Layosa, M.A.A.; Arbizu, S.; Chew, B.P.; Pedrosa, M.L.; Talcott, S.M; Noratto, G.D. Dark sweet cherry (Prunus avium) phenolics enriched in anthocyanins exhibit enhanced activity against the most aggressive breast cancer subtypes without toxicity to normal breast cells. J. Funct. Foods. 2020, 64, https://doi.org/10.1016/j.jff.2019.103710.

7. Numa, I.A.N.; DellaTorre, A.; Oriani, V.B.; Franch Jr, G.C.; Angolini, C.F.F.; Hubinger, M.D.; Ruiz, A.L.T.G.; Pastore, G.M. In vitro bioactivity approach of unripe genipap (Genipa americana L., Rubiaceae) fruit extract and its solid lipid microparticle. Food Res. Internat. 2020, 127, https://doi.org/10.1016/j.foodres.2019.108720.

8. Sharma, P.; Manchanda, R.; Goswami, R.; Chawla, S. Biodiversity and therapeutic potential of medicinal plants. In: Environmental Concerns and Sustainable Development. Shukla, V.; Kumar, N. Eds.; Springer, Singapore. 2020; pp. 27-44, https://doi.org/10.1007/978-981-13-6358-0.

9. Thanasansurapong, S.; Tuchinda, P.; Reutrakul, V.; Pohmakotr, M.; Piyachaturawat, P.; Chairoungdua, A.; Suksenb, K.; Akkarawongsapatc, R.; Limthongkulc, J.; Napaswadc, C.; Nuntasaen, N. Cytotoxic and antiHIV-1 activities of triterpenoids and flavonoids isolated from leaves and twigs of Gardenia sessiliflora. Phytochem Lett. 2020, 35, 46-52, https://doi.org/10.1016/j.phytol.2019.10.007.

10. Dapar, M.L.G.; Demayo, C.G.; Meve, U.; Schumann, S.L.; Alejandro, G.J.D. Molecular confirmation, constituents and cytotoxicity evaluation of two medicinal Piper species used by the Manobo tribe of Agusan del Sur, Philippines. Phytochem. Lett. 2020, 36, 24-31, https://doi.org/10.1016/j.phytol.2020.01.017.

11. Khan, M.; Hanif, M.A.; Rehman, R.; Bhatti, I.A. Black piper. In: Medicinal Plants of South Asia. Elsevier. 2020, 75-86.

12. Kuncari, E.S. Ethnopharmacology and chemical screening of piper from ketambe research station, Gunung Leuser National Park, Southeast Aceh. IOP Conference Series: Earth and Environmental Science. 2020, 457, https://doi.org/10.1088/1755-1315/457/1/012044.

13. Savsani, H., Srivastava, A., Gupta, S., Patel, K., Strengthening antioxidant defense and cardio protection by Piper betle: An in-vitro study. Heliyon. 2020, 6, 1-9, https://doi.org/10.1016/j.heliyon.2019.e03041.

14. Lima, R.N.; Santos, A.D.C.; Ribeiro, A.S.; Cardozo-Filho, L.; Freitas, L.S.; Barison, A.; Costa, E.V.; Alves, P.B. Selective amides extraction and biological activity from Piper hispidum leaves using the supercritical extraction. J. Supercrit. Fluids. 2020, 157, 1-9, https://doi.org/10.1016/j.supflu.2019.104712.

15. Yusop, F.F.; Mughni, N.F.A. Total flavonoid content, total phenolic content and antioxidant activities of ethanol extract for Piper sarmentosum leaf from ten different locations. SA Conference Series: Industrial Revolution 4.0 2020, 1, 141-149.

16. Machado, F.D.S.; Munari, F.M.; Scariot, F.J.; Echeverrigaray, S.; Aguzzoli, C.; PICH, C.T.; Kato, M.J.; Yamaguchi, L.; Moura, S.; Henriques, J.A.P.; Roesch-Ely, M. Piperlongumine induces apoptosis in colorectal cancer HCT 116 cells independent of Bax, p21 and p53 status. Anticancer Res. 2018, 38, 62316236, https://doi.org/10.21873/anticanres.12978.

17. Cheng, X.; Xu, X.; Chen, D.; Zhao, F.; Wang, W. Therapeutic potential of targeting the Wnt/ $\beta$-catenin signaling pathway in colorectal cancer. Biomed. Pharmacoth. 2019, 110, 473-481, https://doi.org/10.1016/j.biopha.2018.11.082. 
18. Iqbal, J.; Abbasi, B.A.; Ahmad, R.; Batool, R.; Mahmood, T.; Kanwal, A.S.; Shah, S.A.; Alam, M.M.; Bashir, S.; Badsha, H.; Munir, A. Potential phytochemicals in the fight against skin cancer: current landscape and future perspectives. Biomed. Pharmacoth. 2019, 109, 1381-1393, https://doi.org/10.1016/j.biopha.2018.10.107.

19. Salehi, B.; Zakaria, Z.A.; Gyawali, R.; Ibrahim, S.A.; Rajkovic, J.; Shinwari, Z.K.; Khan, T.; Sharifi-Rad, J.; Ozleyen, A.; Turkdonmez, E.; Valussi, M.; Tumer, T.B.; Monzote Fidalgo, L.; Martorell, M.; Setzer, W.N. Piper species: a comprehensive review on their phytochemistry, biological activities and applications. Molecules 2019, 24, https://doi.org/10.3390/molecules24071364.

20. Bantal, V.; Ghanta, P.; Tejasvi, P. Piperine presents chemo-preventive property against 1,2-Dimethyl Hydrazine induced colon cancer in mice: biochemical and physiological evidences. Pharmacol. 2018, 9, 3038.

21. Atiya, A.; Salim, M.A.; Sinha, B.N.; Ranjan Lal, U. Two new anticancer phenolic derivatives from leaves of Piper betle Linn. Nat. Prod. Res. 2020, 34, 1-9, https://doi.org/10.1080/14786419.2020.1762186.

22. Wang, R.L.; Gao, Y.; Xing, X. Analysis of chemical composition and assessment of antioxidant, cytotoxic and synergistic antibacterial activities of essential oils from different plant parts of Piper boehmeriifolium. Chem Biodivers 2020, https://doi.org/10.1002/cbdv.202000245.

23. Shi, L.; Qin, H.; Jin, X.; Yang, X.; Lu, X.; Wang, H.; You, D.; Feng, B. The natural phenolic peperobtusin A induces apoptosis of lymphoma U937 cells via the Caspase dependent and p38 MAPK signaling pathways. Biomed. Pharmacoth. 2018, 102, 772-781, https://doi.org/10.1016/j.biopha.2018.03.141.

24. Reynolds, E.S. The use of lead citrate at high $\mathrm{pH}$ as an electron-opaque stain in electron microscopy. J. Cell Biol. 1963, 17, 208-212, https://doi.org/10.1083/jcb.17.1.208.

25. O'brien, T.P.; Feder, N.; McCully, M.E. Polychromatic staining of plant cell walls by toluidine blue O. Protopl. 1964, 59, 368-373, https://doi.org/10.1007/BF01248568.

26. Costa, A.F. Farmacognosia. $2^{\text {nd }}$ ed.; Fundação Calouste Gulbekian: Lisboa, 1982; pp. 1032.

27. Johansen, D.A. Plant microtechique. McGraw-Hill Book Company, Inc.; London, England: $1940 ;$ pp. 533.

28. Pearse, A.G.E. Histochemistry, Preparative and Optical Technology. Churchill Livingstone, Edinburgh London and New York; Volume 1, 1980; pp. 439.

29. Wagner, H.; Bladt, S.; Zgainski, E.M. Plant drug analysis: a thin layer chromatography atlas. $1^{\text {st }}$ ed. Berlim: Springer Verlag; 1984; pp. 320, https://doi.org/10.1007/978-3-642-00574-9.

30. Blois, M.S. Antioxidant determinations by the use of a stable free radical. Nature 1958, 181, 1199-1200, https://doi.org/10.1038/1811199a0.

31. Mosmann, T. Rapid colorimetric assay for cellular growth and survival: application to proliferation and citotoxicity assays. J. Immunol. Meth. 1983, 65, 55-63, https://doi.org/10.1016/0022-1759(83)90303-4.

32. Legrand C.B.J.; Jacob, C.; Capiaumont, J.; Martial, A.; Marc, A. Lactate dehydrogenase (LDH) activity of the cultured eukaryotic cells as marker of the number of dead cells in the medium. J. Biotechnol. 1992, 25, 231-43, https://doi.org/10.1016/0168-1656(92)90158-6.

33. Gogosz, A.M.; Boeger, M.R.T.; Negrelle, R.R.B.; Bergo, C. Comparative leaf anatomy of nine species of the genus Piper (Piperaceae). Rodriguésia. 2012, 63, 405-417, https://doi.org/10.1590/S217578602012000200013.

34. Zermiani, T.; Santos, M.C.; Lobato, F.M.; Blödorn, V.B.; Andrade, F.S.; Lacava, L.C.; Inouea, T.Y.; Ferreira, R.A.; Guimarães, E.F.; Machado, M.S.; Silva, R.M.L.; Malheiros, A. Morphological and phytochemical characterization of Piper mosenii. Nat. Prod. Commun. 2019, 14, 67-70, https://doi.org/10.1177/1934578X1901400118.

35. Htun, S.; Tin, N.N.; Tsin, H.; Naing, T.S. Comparative study on the morphological and anatomical characters of Peperomia pellucida L.(Kunth.) and Piper longum L. in Myitkyina area. $3^{\text {rd }}$ Myanmar Korea Confer. Res. J. 2020, 3(2), 737-744.

36. Souza, L.A.; Moscheta, I.S.; Oliveira, J.H.G. Comparative morphology and anatomy of the leaf and stem of Peperomia dahlstedtii C.DC., Ottonia martiana Miq. and Piper diospyrifolium Kunth (Piperaceae). Gayana Bot. 2004, 61, 6-17, http://doi.org/10.4067/S0717-66432004000100002.

37. Nakamura, A.T.; Simão, E.; Silva, L.; Torres, G.A. Origin of the subepidermal tissue in Piper L. leaves. Braz. J. Biol. 2015, 75, 368-371, https://doi.org/10.1590/1519-6984.13713.

38. Santos, V.L.P.; Raman, V.; Bobek, V.B.; Migacz, I. P.; Franco, C.R.C.; Khan, I.A.; Budel, J.M. Anatomy and microscopy of Piper caldense, a folk medicinal plant from Brazil. Ver. Bras. Farmacogn. 2018, 28, 915, https://doi.org/10.1016/j.bjp.2017.11.004.

39. Hashmi, M.A.; Khan, A.; Farooq, U.; Khan, S. Alkaloids as cyclooxygenase inhibitors in anticancer drug discovery. Curr. Protein Pept. Sci. 2018, 19, 292-301.

40. Montag, G.; Stopper, H.; Ngo, Q.A.; Hintzsche, H. The biological activity of the novel vinca alkaloids 4chlorochablastine und 4-chlorochacristine. Curr. Can. Drug Targ. 2018, 18, 222-230.

41. Khan, M.S.; Qais, F.A.; Ahmad, I. Indian berries and their active compounds: therapeutic potential in cancer prevention. In: New Look Phytomedicine. Academic Press. 2019; pp. 179-201.

42. Jing Y.; Zhang H.J.; Wang, K.W.; Wang, X.X.; Chen, M.L.; Wang, H.; Wu, B. Two novel anthraquinones with cytotoxicity from Hedyotis caudatifolia. Phytochem. Lett. 2019, 29, 134-137. https://doi.org/10.1016/j.phytol.2018.11.026. 
43. Patil, V.M.; Masand, N. Anticancer potential of flavonoids: chemistry, biological activities, and future perspectives. In: Studies in Natural Products Chemistry. Rahman, A. Ed.; Elsevier, New York. 2019; pp. 401-430, https://doi.org/10.1016/B978-0-444-64179-3.00012-8.

44. Pan, J.H.; Abernathy, B.; Kim, Y.J.; Lee, J.H.; Kim, J.H.; Shin, E.C.; Kim, J.K. Cruciferous vegetables and colorectal cancer prevention through microRNA regulation: A review. Crit. Rev. Foods Sci. Nutr. 2018, 58, 2026-2038, https://doi.org/10.1080/10408398.2017.1300134.

45. An, Y.; Quan, K.T.; Gwak, J.; Ju, B.G.; Na, M.; Oh, S. Activation of the p53 pathway with digiferrol isolated from Rubia philippinensis induces cell cycle arrest, apoptosis, and autophagy in colon cancer cells. Food Chem. Toxicol. 2018, 118, 514-522, https://doi.org/10.1016/j.fct.2018.05.054.

46. Reichling, J. Plant-microbe interactions and secondary metabolites with antiviral, antibacterial and antifungal properties. Ann. Plant Rev. 2018, 189-279, https://doi.org/10.1002/9781119312994.apr0022.

47. Singh, S.K. Explorations of plant's chemodiversity: role of nitrogen-containing secondary metabolites in plant defense. In: Molecular aspects of plant-pathogen interaction. Springer, Singapore; 2018; pp. 309-332, https://doi.org/10.1007/978-981-10-7371-7_14.

48. Yang, L.; Wen, K.S.; Ruan, X.; Zhao, Y.X.; Wei, F.; Wang, Q. Response of plant secondary metabolites to environmental factors. Molecules 2018, 23, https://doi.org/10.3390/molecules23040762.

49. Wink, M. Introduction: biochemistry, role and biotechnology of secondary metabolites (From APR Vol. 3). Ann. Plant Rev. 2018, 1-17, https://doi.org/10.1002/9781119312994.apr0018.

50. Aara, A.; Chappidi, V.; Ramadas, M.N. Antioxidant activity of eugenol in Piper betel leaf extract. J. Fam. Med. Prim. Care. 2020, 9, 327-331, https://doi.org/10.4103/jfmpc.jfmpc_809_19.

51. Silva, M.A.; Silva, F.B.; Passarini, G.M.; Fialho, S.N.; Santos, A.P.D.A.; Martinez, L.D.N.; Teles, C.B.G.; Kuehn, C.C. Piplartine and piperine: a review of their biological activities. South Am J Basic Educat, Tech Technol. 2019, 6, 818-858.

52. Bhagya, N.; Chandrashekar, K.R. Identification and quantification of cytotoxic phenolic acids and flavonoids in Ixora brachiata by UHPLC-DAD and UHPLC-ESI-MS/MS. Int. J. Mass Spectrom. 2020, 450, 116-290, https://doi.org/10.1016/j.ijms.2020.116290. 